\title{
The concept of modification and analysis of the strength of steel roadway supports for coal mines in the Soma Basin in Turkey
}

https://doi.org/10.2478/sgem-2018-0006

received January 12, 2018; accepted March 23, 2018.

Abstract: The article presents a comparison of the roadway supports currently used in mines in the Soma basin in Turkey with new one proposed by Huta Łabędy and Central Mining Institute (GIG) in terms of resistance parameters and work in conditions of specific loads. The strength analysis of the frame was carried out using the finite element method, using the COSMOS/M program, based on the methodology developed and applied in GIG.

The frame models were built corresponding to their geometry and cross-sectional parameters of the sections used. Beam elements (BEAM3D) were used for building models, which were given cross-sectional parameters of the V36 section. This resulted in three frame models that were loaded in three ways (three load variants). The first option included roof load, acting on the roof bar in a uniform manner, at a length of about $3.0 \mathrm{~m}$. In the second variant, the same load was adopted but the resistance of the side wall was omitted. However, in the third variant, the same roof load was assumed in addition to a side load, acting on the sliding arch, at a length of about $3.0 \mathrm{~m}$, a value corresponding to half the load of the roof. As a result of the calculations carried out, the distribution of reduced stresses in the analysed frames and the maximum load values were obtained.

The proposed roadway supports retain the functionality of the previously used frames in terms of width, height, cross-sectional area of the support and the number of elements. They are characterised by the same weight and at the same time, they have up to $24 \%$ more load capacity because of the replacement of straight sections of curved side sections. This treatment was possible by forming individual elements of the arch with two bending radii. The additional load increase was obtained by using S550W steel.

Keywords: projects; roadway suppor; strength analysis.

\section{Introduction}

The Soma basin is located in western Turkey in the province of Manisa (Fig. 1). Mines are located in areas completely intended for industrial purposes - primarily for coal mines (deep and opencast mines) and mineral resources (quarries). The lignite deposit with a thickness of up to $30 \mathrm{~m}$, lying at a depth of up to $700 \mathrm{~m}$ below the surface of the mountainous terrain, is used. In most cases, the deposit is made available by two parallel inclines from the surface. The transport of output, materials and crew is carried out using conveyor belts and suspended overhead lines. Exploitation is most often carried out by longwall top coal caving (LTCC) system for two or three layers with a three-year time shift. There is a significant difficulty in using the LTCC system, which results from increased loads acting on the support of longwall gates [1,2], associated with the operation of a significant seam thickness. Such a state of loading increases the role of roadway support protecting these excavations. Its proper selection and installation should provide security of the whole mining cycle. In this case, strength parameters of applied support and operational characteristics of frictional joints play a significant role $[3,4,5]$. These values decide about the functionality of support.

The goal was to propose a new supports solution for the Soma basin conditions.

*Corresponding author: Marek Rotkegel, Gtówny Instytut Górnictwa, E-mail: m.rotkegel@gig.eu

Marek Grodzicki: Huta tabędy S.A.

ə Open Access. (๑) 2018 Marek Grodzicki, Marek Rotkegel, published by Sciendo. @) Br-Nc-ND This work is licensed under the Creative Commons Attribution-NonCommercial-NoDerivatives 4.0 License. 


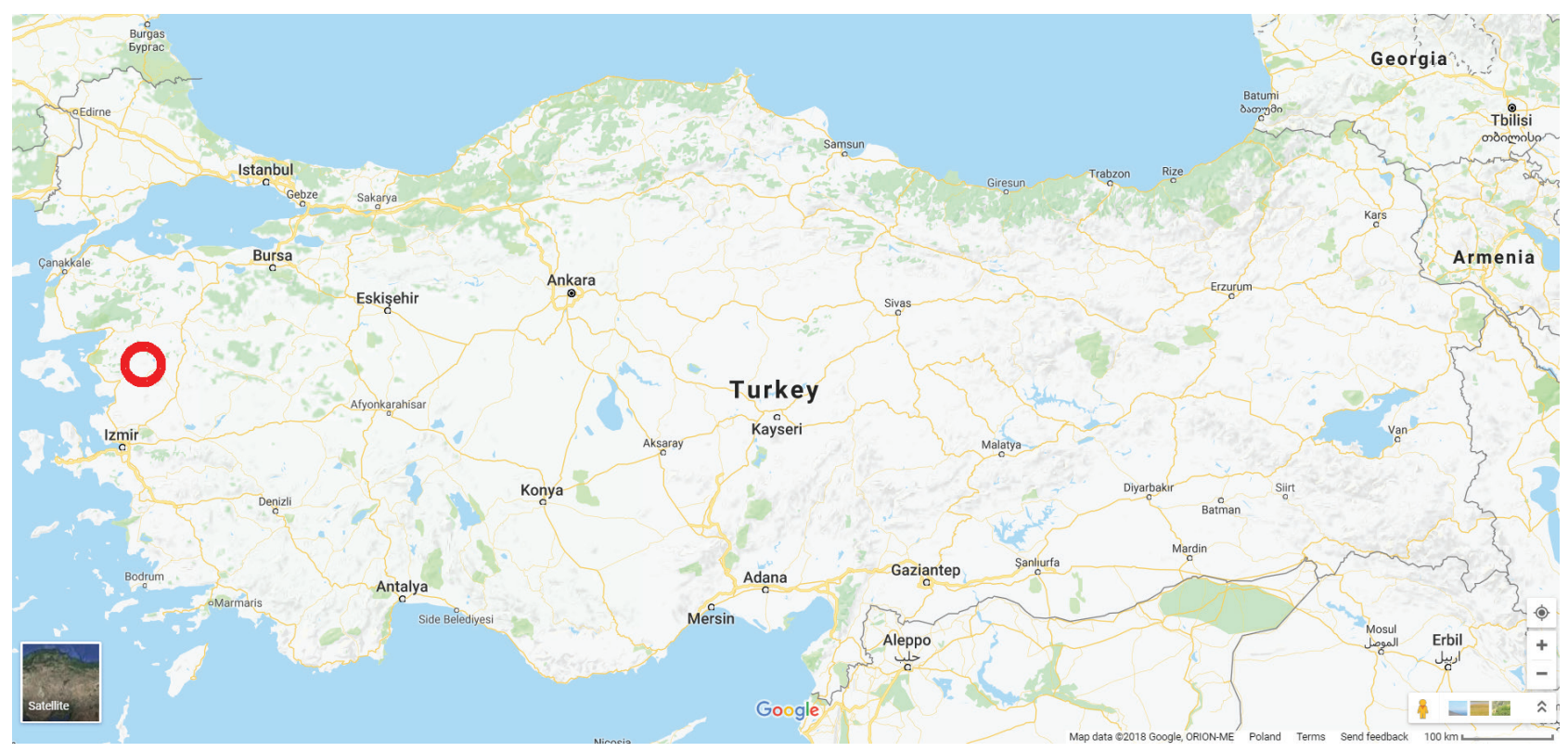

Figure 1: Location of the Soma basin (Google Maps).

\section{Working support currently in use}

Both in access and in preparation workings, a standing support is used - a steel arched frame (sometimes trapezoidal), mainly yielding from V34 or V36 sections made of S480W steel (Fig. 2). The support predominantly has inner dimensions of $5.7 \mathrm{~m} \times 4.3 \mathrm{~m}$, with the crosssectional area of the excavation of about $20 \mathrm{~m}^{2}$, as shown in Figure 3. This support is characterised by a very long straight section, which is the cause of many problems. Such a shape of the section of the excavation, especially its height, results from the equipment and mainly from the use of monorails and conveyor belts for transporting the crew in both directions - on the upper and lower belts. Roadway supports are built with spacing of $0.75-1.20 \mathrm{~m}$ and are stabilised by means of massive sprags (e.g. based on the c-section) built most often in 8 lines. Welded mesh is used as lagging. In many places, the lack of backfilling or backfilling carelessness was noticed, which adversely affects the stability of the excavation and causes premature damage to the support.

\section{Proposed changes in support construction}

Owing to the observed significant deformations, and even damage to the sliding arches, especially on the straight section, a housing has been proposed with a slightly

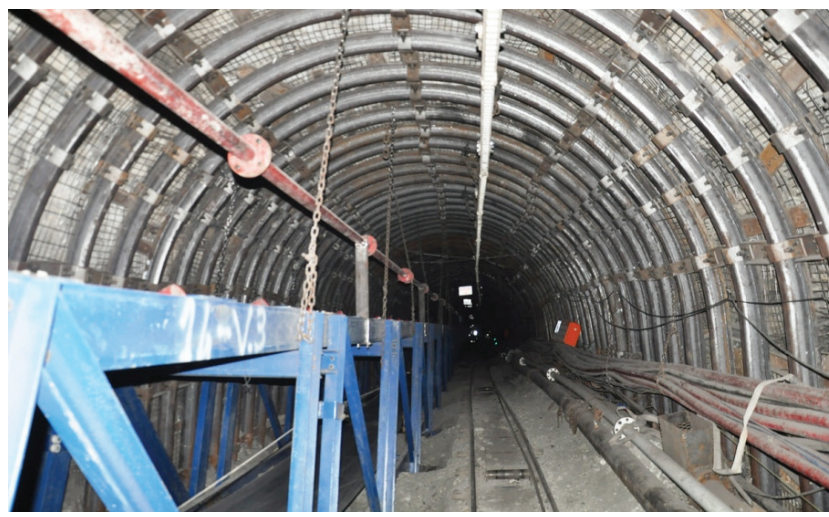

Figure 2: General view of the gallery [11].

modified contour. Three-element steel frames were designed, consisting of one roof arch and two side-wall arches, which were characterised by two curvatures. From the side of the excavation floor (foundation of the frames), a smaller curvature (larger radius of bending) was used, whilst from the vault side, a higher curvature (smaller bending radius) was adapted to the curvature of the roof arch. The elements are joined by overlap with clamps. Figure 4 shows the outline and characteristic dimensions of the frame section of approximately $20 \mathrm{~m}^{2}$. 

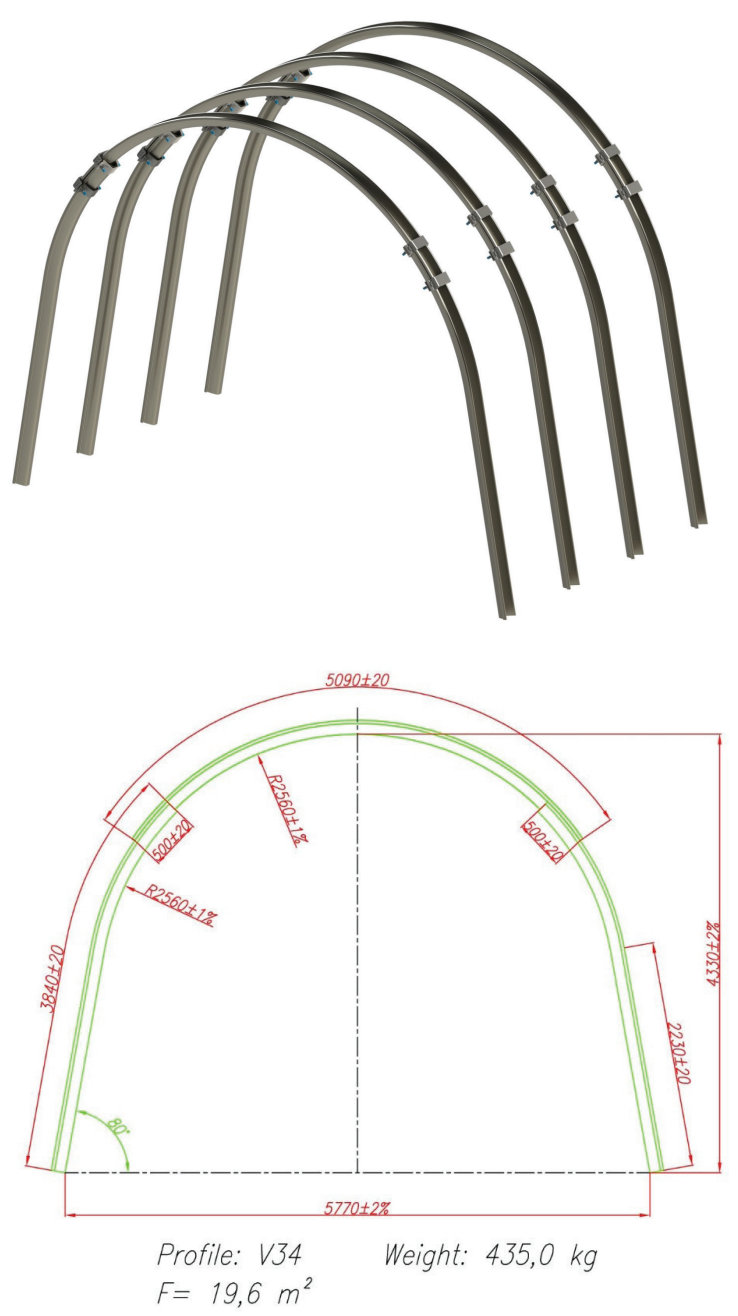

Figure 3: The shape of the frame and basic geometrical parameters.

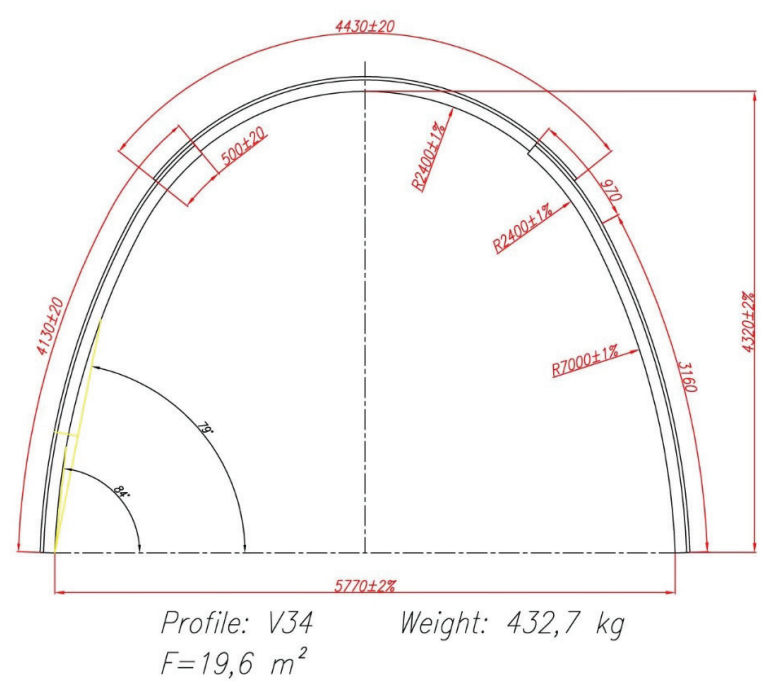

Figure 4: The proposed outline of the frame of approximately $20 \mathrm{~m}^{2}$.

\section{Numerical analysis}

A comparison of the frames currently used with the proposed frames was carried out with the scope of their resistance parameters and work in the conditions of loads occurring in the Soma basin mines. The strength analysis of the frame was carried out using the finite element method [7,9], using the COSMOS/M program [10], with the methodology developed and used in GIG. The essence of FEM is the division (discretisation) of a complex system into a finite number of elements, analysis of a single element whose behaviour is determined by a finite number of parameters and then reassembly of all elements to study the entire system's response. It is easier to examine and understand the response of a single element and then re-build a complex system to study its response, rather than examine the whole system [6].

From the user's point of view, modelling in the COSMOS/M system comes down to introducing the geometry of the whole system under examination and determining the parameters of its individual parts. These parameters are material properties, cross-sectional parameters and material curves for non-linear analysis. The geometry of the system can be given by creating it in the GEOSTAR module or by importing a threedimensional drawing in dxf format, for example, from AutoCAD. Inconvenient discretisation, especially in the case of complex models, is carried out by the program in a semi-automatic manner, under the user's control.

After entering the above data, it is necessary to determine the way of loading and supporting the model. As a result of calculations, the values of internal forces automatically converted to reduced stresses are obtained.

Before starting the proper analysis, the cross-sectional and strength parameters of the sections intended for use on the frames were determined.

The maximum stresses that are able to transfer the elements of the frame (taking into account the plastic deformation and the local loss of the cross-section stability) can be determined from dependence [8]:

$$
\sigma_{d o p}=\frac{R_{e} \cdot(m+n)}{\gamma_{s}}
$$

The material factor $\gamma_{s}$ in accordance with the PN-B-03200 standard depends on the material yield strength. Its values for steel used for mining arches are presented in Table 1.

However, the material coefficient of plasticity is determined from the dependence of 


$$
n=\frac{R_{m}-R_{e}}{R_{e}}
$$

The values of this coefficient in the case of steel used for manufacturing frames were collected in Table 2.

The coefficient $m$ of the plastic reserve of the cross section is equal to the ratio of the plastic resistance index to the bending section strength index:

$$
m=\frac{W_{p l}}{W_{x}}
$$

wherein the plastic resistance index is equal to the sum of the absolute values of the static moments of the compressed $S_{c}$ and the tensioned $S_{\mathrm{r}}$ of the sectional area relative to the neutral axis in the fully plasticised state. Thus, you can write

$$
W_{p}=\left|S_{c}\right|+\left|S_{r}\right|
$$

The cross-sectional parameters of the V36 profile calculated in the above manner are collected in Table 3.

$A$, cross-sectional area of the section; $H$, section height; $B$, section width; $e$, position of the neutral axis in elastic bending; $e_{p}$, position of the neutral axis in plastic bending; $I$, main central moment of inertia of the cross-

Table 1: Material factor $\gamma_{s}$.

\begin{tabular}{llll}
\hline Steel grades & $\mathbf{V}_{\mathrm{s}}$ & $\mathbf{R}_{\mathrm{e} \text { min. }}(\mathrm{MPa})$ & $\mathbf{R}_{\mathrm{m} \text { min. }}(\mathrm{MPa})$ \\
\hline 25G2; 31Mn4 & 1.15 & 340 & 550 \\
S480W & 1.25 & 480 & 650 \\
S550W & 1.25 & 550 & 730 \\
\hline
\end{tabular}

Table 2: Material plasticising coefficient

\begin{tabular}{ll}
\hline Steel grades & $\mathbf{n}$ \\
\hline 25G2; 31Mn4 $\left(R_{e}=340 \mathrm{MPa}, R_{m}=550 \mathrm{MPa}\right)$ & 0.6176 \\
S480W $\left(R_{e}=480 \mathrm{MPa}, R_{m}=650 \mathrm{MPa}\right)$ & 0.3542 \\
S550W $\left(R_{e}=550 \mathrm{MPa}, R_{m}=730 \mathrm{MPa}\right)$ & 0.3273 \\
\hline
\end{tabular}

section; $W$, elastic section modulus; $W_{p p}$, plastic section modulus; $\sigma_{\text {dop25G2 }}$, allowable stresses for S25G2 steel sections; $\sigma_{\text {dops480w }}$, allowable stresses for S480W steel sections; $\sigma_{\text {dop5550W }}$, allowable stresses for S550W steel sections.

Computer programs operating based on the FEM algorithm, in addition to displacements and internal forces, automatically calculate the stresses reduced according to the Huber-Mises-Hencky hypothesis, according to the general dependence:

$\sigma_{r e d}=\sqrt{\sigma_{x}^{2}+\sigma_{y}^{2}+\sigma_{z}^{2}-\sigma_{x} \sigma_{y}-\sigma_{x} \sigma_{z}-\sigma_{y} \sigma_{z}+3 \cdot\left(\tau_{x y}^{2}+\tau_{x z}^{2}+\tau_{y z}^{2}\right)}$

By treating the frame as a flat system and analysing stresses in cross sections perpendicular to the axis of the section, the above equation simplifies to the following form:

$$
\sigma_{\text {red }}=\sqrt{\sigma^{2}+3 \cdot \tau^{2}}
$$

By breaking down the stresses on the appropriate loads related to the $W_{x}$ modulus and the cross-sectional area $A$, the following equation is obtained:

$$
\sigma_{r e d}=\sqrt{\left(\frac{M_{g}}{W_{x}}+\frac{N}{A}\right)^{2}+3 \cdot\left(\frac{T}{A}\right)^{2}}
$$

where $M_{g}$ is the bending moment, $N$ is the axial force (longitudinal), $T$ is the transverse force (shear), $W_{x}$ is the section modulus, $A$ is the cross-sectional area, $\sigma$ is the normal stresses and $\tau$ is the shear stress.

Acting according to the above course, the support parameters of the frames currently used with the proposed ones were calculated and compared.

First of all, frame models were built corresponding to their geometry and cross-sectional parameters of the sections used. Beam elements (BEAM3D) were used for building models, which were given the cross-sectional parameters of the V36 section. In addition, SPRING elements were used, which modelled the impact of the sidewalls. In this way, three frame models were created, which were loaded in three ways (3 load variants). The first option included roof load, operating the roof bar

Table 3: Cross-sectional mechanical parameters of V36 profile

\begin{tabular}{lllllllllllllll}
\hline Profile & $\mathbf{A}$ & $\mathbf{H}$ & $\mathbf{B}$ & $\mathbf{e}$ & $\mathrm{I}_{\mathrm{x}}$ & $\mathrm{I}_{\mathrm{y}}$ & $\mathbf{W}_{\mathrm{x}}$ & $\mathbf{W}_{\mathrm{y}}$ & $\mathbf{e}_{\mathrm{pl}}$ & $\mathbf{W}_{\mathrm{plx}}$ & $\mathbf{m}$ & $\boldsymbol{\sigma}_{\text {dop2562 }}$ & $\boldsymbol{\sigma}_{\text {dop5480W }}$ & $\boldsymbol{\sigma}_{\text {dop5550w }}$ \\
\cline { 2 - 11 } & $\mathbf{c m}^{2}$ & $\mathbf{m m}$ & $\mathbf{m m}$ & $\mathbf{m m}$ & $\mathbf{c m}^{4}$ & $\mathbf{c m}^{4}$ & $\mathbf{c m}^{3}$ & $\mathbf{c m}^{3}$ & $\mathbf{m m}$ & $\mathbf{c m}^{3}$ & - & $\mathbf{M P a}$ & $\mathbf{M P a}$ & $\mathbf{M P a}$ \\
$\mathrm{V} 36$ & 45.16 & 138 & 171 & 65.68 & 923 & 1229 & 127.64 & 143.74 & 61.57 & 185.72 & 1.455 & 612 & 694 & 784 \\
\hline
\end{tabular}


evenly, at a length of about $3.0 \mathrm{~m}$. In the second variant, the same load was accepted but the resistance of the side wall was omitted. However, in the third variant, the same roof load was assumed in addition to a side load, acting on a wall arch, at a length of about $3.0 \mathrm{~m}$, with a value corresponding to half of the ceiling load $\left(q_{o}=0.5 \mathrm{q}_{\mathrm{s}}\right)$. The list of frame models is presented in Table 4, and in load variants are given in Figures 5-7.

The analyses were carried out in several stages. In the first stage, the values of maximum stresses in the frames

Table 4: Models analysed.

\begin{tabular}{llll}
\hline Model designation & Arch support & Section & Steel grade \\
\hline A & Current & V36 & S480W \\
B & Proposed & V36 & S480W \\
C & Proposed & V36 & S550W \\
\hline
\end{tabular}

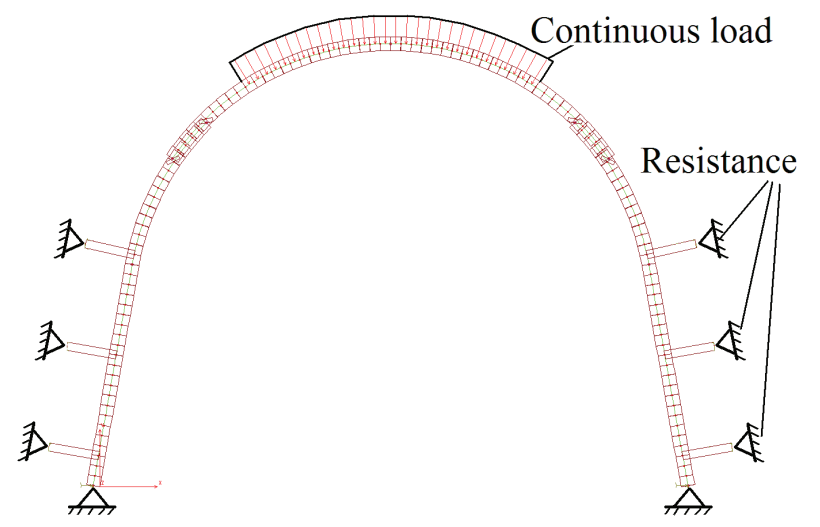

Figure 5: Variant I of the load on the frame.

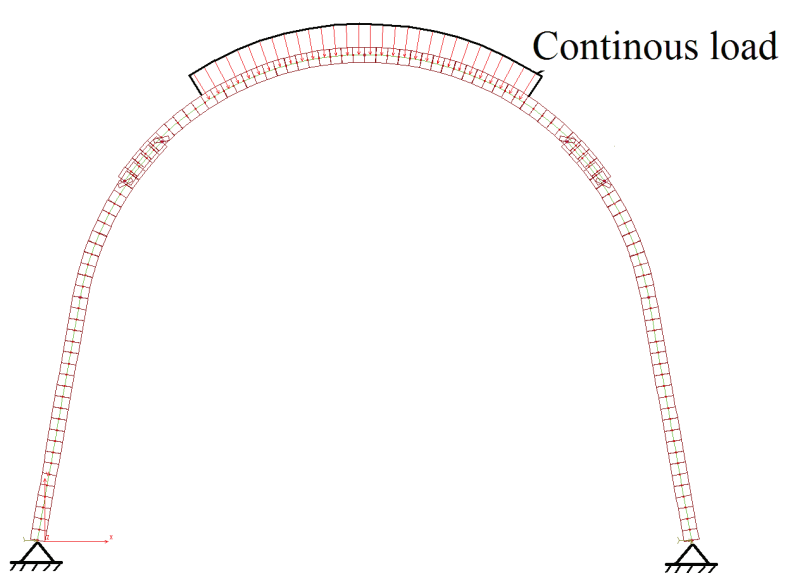

Figure 6: Variant II of the load on the frame.

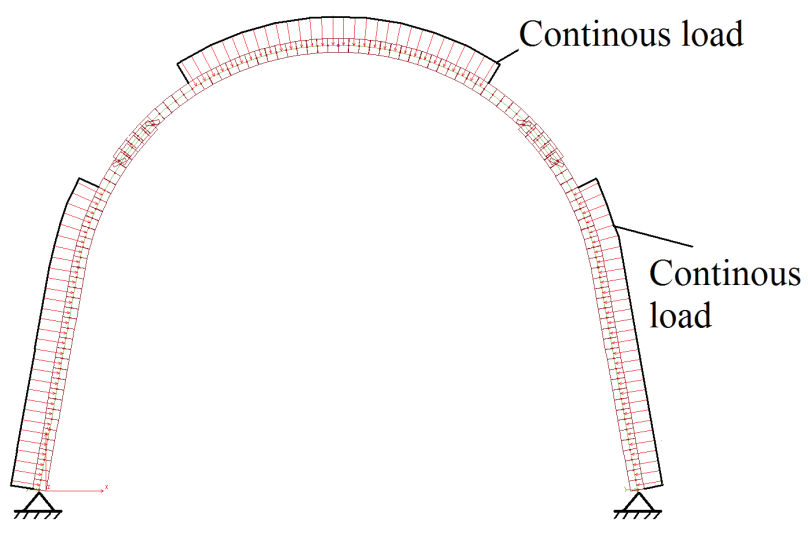

Figure 7: Variant III of the load on the frame.

caused by the unit load were determined, the same in all the analysed models (A, B and C). The results are summarised in Table 5. As you can see, the same load causes different values of stresses in the frames, depending on the load pattern and the shape. In the case of the proposed frame (B and C), the stresses are lower by a few percent when compared with the currently used frames loaded in the same way. Figures 8-10 shows coloured stress maps in the frames, and a summary of the results is given in Figure 11.

In the next step, the maximum loads that the analysed frames were able to transfer were calculated. For this purpose, the load has been increased to reach allowable stresses (Table 3). As a result of the calculations carried out, the distribution of reduced stresses in the analysed frames and load values was obtained. Coloured stress maps are shown in Figures 12-14, and the list of load capacity of the frames is given in Figure 15 and Table 6.

As it results from the presented specification, the proposed frame has a higher load capacity than the previously used frame. This applies to all analysed load schemes (variants).

\section{Summary and Conclusions}

As a result of the observations and analyses carried out, a new roadway supports was designed dedicated to securing excavations in the Soma mines. As part of the work, comparative strength analyses of frames in three load variants were carried out. For this purpose, three models of the frame were built: A, the currently used frames from the V-section in the S480W grade; $\mathrm{B}$, the proposed frames of the V-section in the S480W; and C grade, the proposed frames of the V-section in the S550W grade. 
Table 5: Maximum stress values in the analysed arch supports

\begin{tabular}{|c|c|c|c|}
\hline \multirow[t]{2}{*}{ Model designation } & \multicolumn{3}{|l|}{ Load scheme } \\
\hline & $\begin{array}{l}\text { I } \\
\left(q_{s}=0.1 \mathrm{MN} / \mathrm{m}\right. \\
+ \text { resist the side wall) }\end{array}$ & $\begin{array}{l}\text { II } \\
\left(q_{s}=0.1 \mathrm{MN} / \mathrm{m}\right. \\
+ \text { no side wall resistance })\end{array}$ & $\begin{array}{l}\text { III } \\
\left(q_{s}=0.1 \mathrm{MN} / \mathrm{m}\right. \\
\left.+q_{0}=0.05 \mathrm{MN} / \mathrm{m}\right)\end{array}$ \\
\hline A (current V36, S480W) & $\mathrm{s}_{\max }=310.7 \mathrm{MPa}$ & $\mathrm{s}_{\max }=609.1 \mathrm{MPa}$ & $\mathrm{S}_{\max }=327.3 \mathrm{MPa}$ \\
\hline $\begin{array}{l}\text { B (proposed V36, S480W) } \\
\text { C (proposed V36, S550W) }\end{array}$ & $\mathrm{S}_{\max }=268.2 \mathrm{MPa}$ & $\mathrm{S}_{\max }=578.3 \mathrm{MPa}$ & $\mathrm{S}_{\max }=262.6 \mathrm{MPa}$ \\
\hline
\end{tabular}

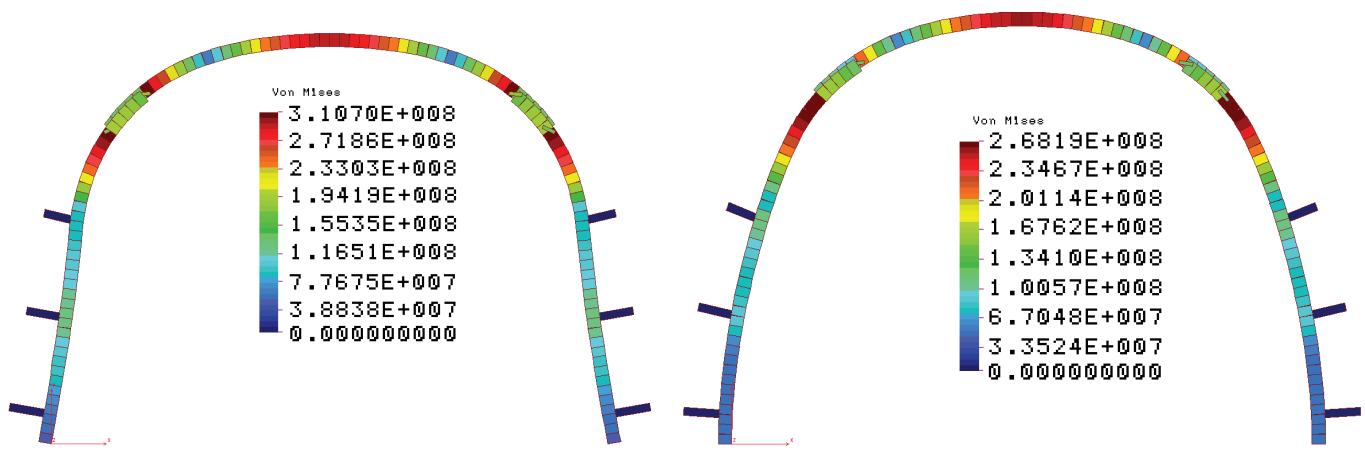

Figure 8: The map of reduced stresses in the A (left) and B and C (right) frames for load scheme I $\left(q_{s}=0.1 \mathrm{MN} / \mathrm{m}\right.$, stresses in Pa, deformation scale 10x).

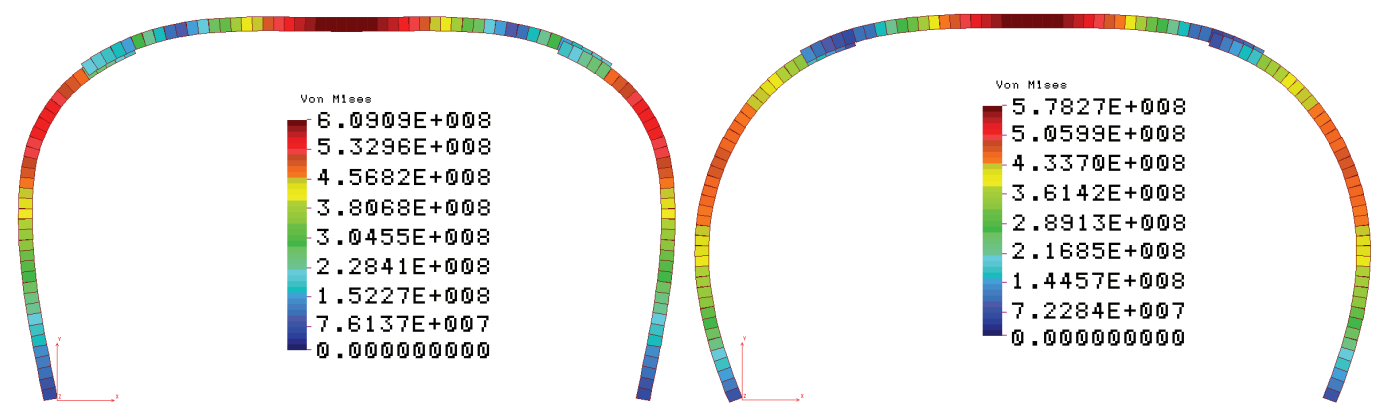

Figure 9: The map of reduced stresses in the A (left) and B and C (right) frames for load scheme II $\left(q_{s}=0.1 \mathrm{MN} / \mathrm{m}\right.$, stresses in Pa, deformation scale $10 \times$ ).

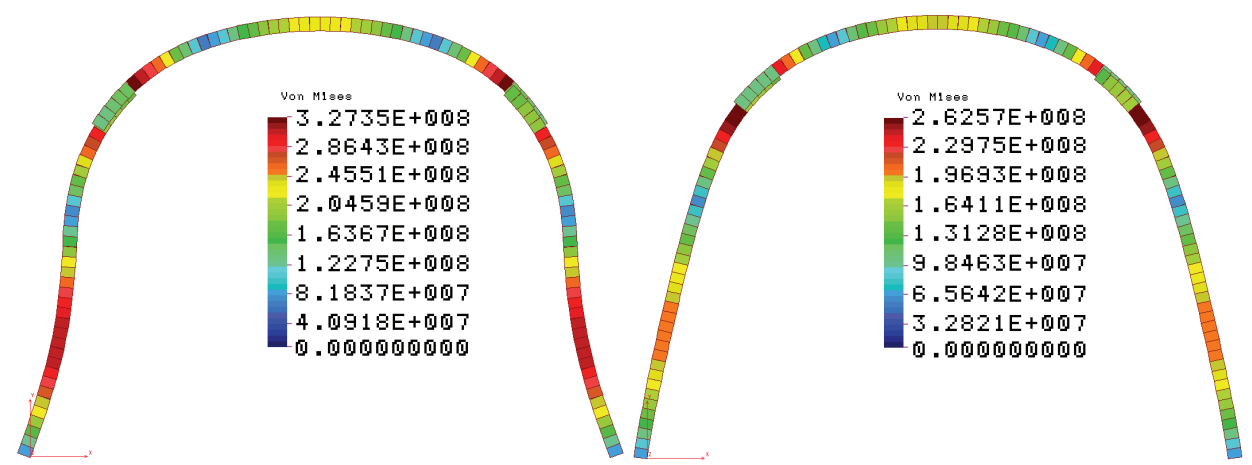

Figure 10: The map of reduced stresses in the A (left) and B and C (right) frames for load scheme III $\left(q_{\mathrm{s}}=0.1 \mathrm{MN} / \mathrm{m}\right.$, stresses in Pa, deformation scale $10 \times$ ). 
Maximum stress, MPa

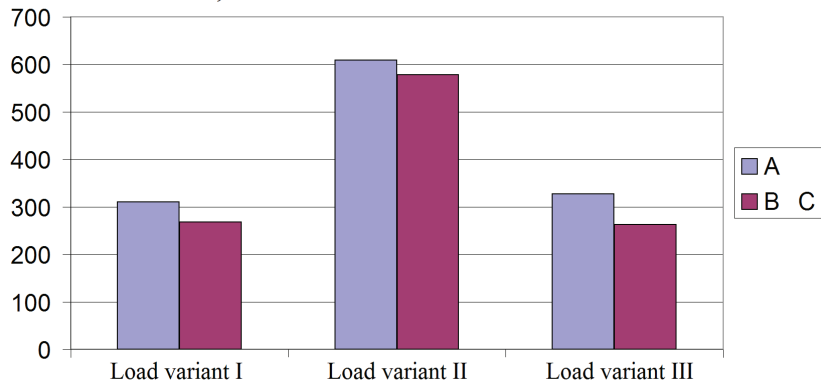

Figure 11: Comparison of maximum stresses in arch support A and B and $\mathrm{C}$ for different load patterns.
The constructed models correspond to the geometry and cross-sectional parameters of the sections used. Next the values of maximum stresses in frames caused by the same unitary load were determined. As a result, the maximum loads that are able to carry the frame were calculated.

The conducted analysis showed that changing the frame's geometry consisting in the elimination of straight sections of elements results in reducing the stress by up to $20 \%$. The proposed frame structure retains the functionality previously used in the field of width, height, finished cross-sectional area of working and the number of elements. They are characterised by the same mass, and, at the same time, their load capacity increases by

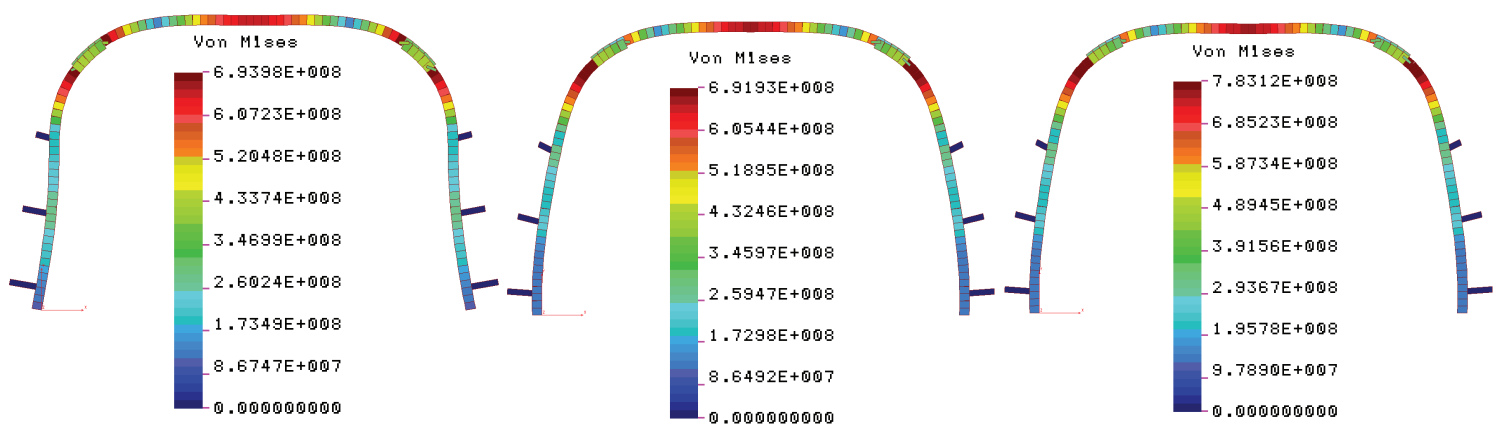

Figure 12: Map of reduced stresses in A (left), B (middle) and C (right) frames for load scheme - variant I (stresses in Pa, deformation scale 10x).

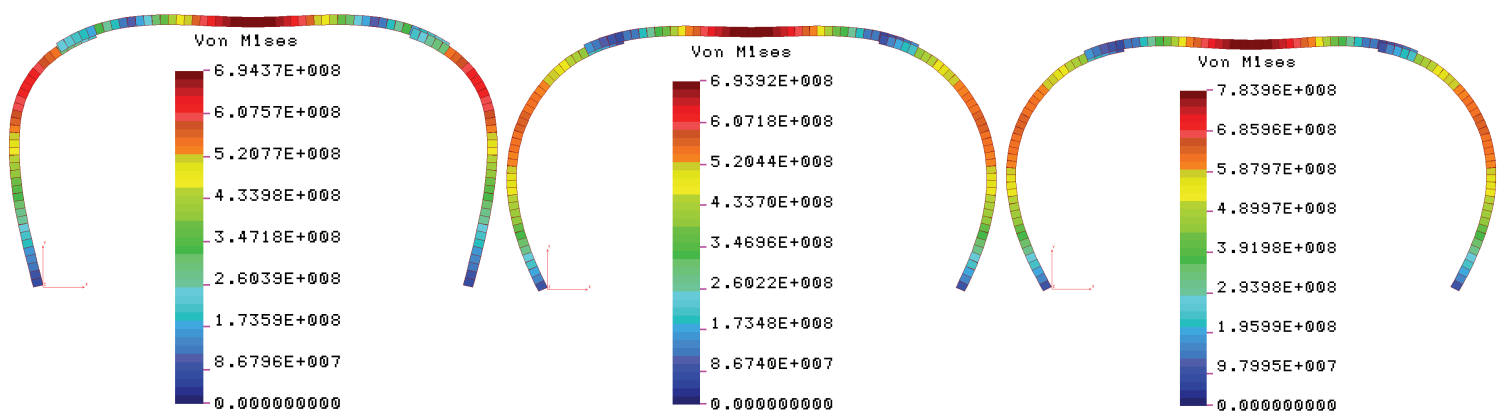

Figure 13: Map of reduced stresses in A (left), B (middle) and C (right) frames for load scheme - variant II (stresses in Pa, deformation scale 10x).

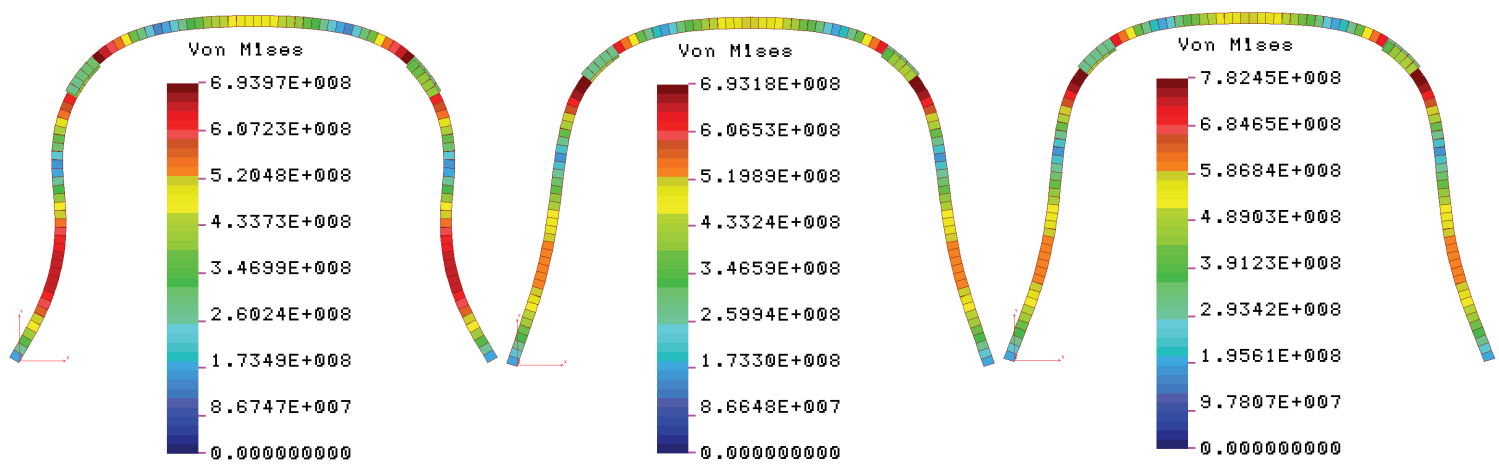

Figure 14: Map of reduced stresses in A (left), B (middle) and C (right) frames for load scheme - variant III (stresses in Pa, deformation scale 10x). 
Table 6: Maximum load values transmitted by the arch support.

\begin{tabular}{|c|c|c|c|c|c|c|}
\hline \multirow{3}{*}{$\begin{array}{l}\text { Model designation } \\
\text { A (current V36, S480W) }\end{array}$} & \multicolumn{6}{|l|}{ Load variant } \\
\hline & \multicolumn{2}{|c|}{ I (roof load + wall resistance) } & \multicolumn{2}{|c|}{ II (roof load + no side wall resistance) } & \multicolumn{2}{|c|}{ III (roof load + side load) } \\
\hline & $\mathrm{F}_{\max }=669 \mathrm{kN}$ & $100 \%$ & $\mathrm{~F}_{\max }=342 \mathrm{kN}$ & $100 \%$ & $\mathrm{~F}_{\max }=636 \mathrm{kN}$ & $100 \%$ \\
\hline B (proposed V36, S480W) & $\mathrm{F}_{\max }=774 \mathrm{kN}$ & $115 \%$ & $\mathrm{~F}_{\max }=360 \mathrm{kN}$ & $105 \%$ & $\mathrm{~F}_{\max }=792 \mathrm{kN}$ & $124 \%$ \\
\hline C (proposed V36, S550W) & $\mathrm{F}_{\max }=877 \mathrm{kN}$ & $131 \%$ & $\mathrm{~F}_{\max }=407 \mathrm{kN}$ & $119 \%$ & $\mathrm{~F}_{\max }=896 \mathrm{kN}$ & $140 \%$ \\
\hline
\end{tabular}

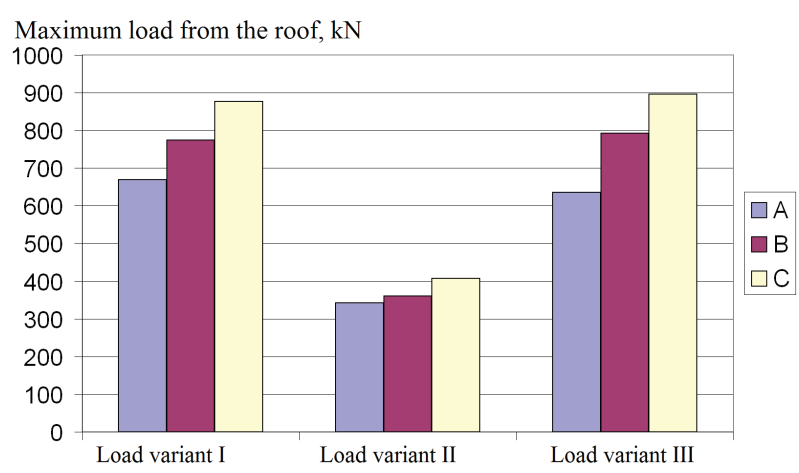

Figure 15: Comparison of the maximum load capacity of arch support $A, B$ and $C$ for different load patterns.

$24 \%$ because of the replacement of straight sections of elements with arc sections. This treatment was possible by forming the arches of the side walls with two radii of bending. In addition, if the new steel grade is used S550W - the increase in frame strength reaches $40 \%$.

\section{References}

[1] Alehossein H., Poulsen B.A., Stress analysis of longwall top coal caving. International Journal of Rock Mechanics \& Mining Science 47, 2010, 30-41.

[2] BILIŃSKI A., Metoda doboru obudowy ścianowych wyrobisk wybierkowych i chodnikowych do warunków pola eksploatacyjnego. Prace naukowe - Monografie CMG KOMAG. Gliwice 2005, 1-109.

[3] BRODNY J., Determining the working characteristic of a friction joint in a yielding support. Archives of Mining Sciences, Vol. 55 (2010), No 4, p. 733-746.

[4] BRODNY J., Tests of friction joints in mining yielding supports under dynamic load. Archives of Mining Sciences, Vol. 56 (2011), No 2, p. 303-318.

[5] BRODNY J., Analysis of operation of new construction of the frictional joint with the resistance wedge. Archives of Mining Sciences, Vol. 57 (2012), No 1, p. 209-227.
[6] Chmielewski T., Nowak H., Mechanika budowli. Metoda przemieszczén. Metoda Crossa. Metoda elementów skończonych. Wydawnictwa Naukowo-Techniczne. Warszawa 1996, 1-209.

[7] Cook R.D., Malkus D.S., Plesha M.E., Witt R.J., Concepts and applications of finite element analysis. John Wiley \& Sons, Inc. New York 2002.

[8] MAJCHERCZYK T. + ZESPót: Sposoby i możliwości korzystania z katalogu rozwiązań obudowy dla rozcinek ścianowych (Materiały konferencyjne). Stowarzyszenie Inżynierów i Techników Górnictwa, Koło Zakładowe przy GIG, Ustroń, 1998, 1-26.

[9] RAKOWSKı G., KACPRZYK Z., Metoda elementów skończonych w mechanice konstrukcji. Oficyna Wydawnicza Politechniki Warszawskiej, Warszawa 1993, 1-457.

[10] Rusıńskı E., Metoda elementów skończonych. System COSMOS/M. Wydawnictwa Komunikacji i Łączności, Warszawa 1994, 1-376

[11] www.imbatmadencilik.com (07.12.2017). 